\section{A Simple and Rapid Method to Analyze Specific mRNAs from Few Cells in a Semi-quantitative Way Using the Polymerase Chain Reaction}

\author{
J. Golay, F. Passerini, \\ and $\mathrm{M}$. Introna
}

Istituto Ricerche Farmacologiche Mario Negri, 20157 Milan, Italy
A situation commonly encountered in the laboratory is one in which comparison of the relative levels of expression of specific genes in highly purified populations of cells or in clinical samples would be very useful but is problematic due to the small amount of material available. Therefore, we have devised a simple and rapid method to analyze in a semi-quantitative way mRNAs from relatively few cells using the polymerase chain reaction (PCR). This method is particularly useful for rapid determination of the effect of differentiative agents, cytokines, antisense oligonucleotides, or pharmaceutical agents on the expression of specific genes in a semi-quantitative way. It could also be used to detect and quantify minimal residual disease where few cells are available for study.

\section{METHOD}

We tested several published methods for isolating RNA from few cells and found that the best method for our purpose was by guanidine thiocyanate and a modified acid phenol extraction. ${ }^{(1)}$ This method gives undegraded RNA and is highly reproducible in its efficiency of both RNA extraction and subsequent reverse transcription, factors that are important for adequate quantification. The method described below works well for $1-10 \times 10^{3}$ cells in the case of hematopoietic lines and 10 times that number in the case of normal lymphocytes.

Briefly, the cells are washed once in sterile saline and the pellet is resuspended by vortexing in $150 \mu \mathrm{l}$ of guanidine thiocyanate solution $(4.2 \mathrm{M})$ containing $0.5 \%$ sodium lauryl sarcosinate, $25 \mathrm{~mm}$ sodium citrate $(\mathrm{pH} 7)$, $100 \mathrm{~mm}$ 2-mercaptoethanol, and $1 \mu \mathrm{g}$ of $E$. coli RNA. To this are added $4.5 \mu \mathrm{l}$ of $2 \mathrm{M}$ sodium acetate ( $\mathrm{pH} 4), 180 \mu \mathrm{l}$ of water-saturated phenol, and $35 \mu \mathrm{l}$ chloroform. The samples are vortexed, put on ice $10 \mathrm{~min}$, and then centrifuged at $12,000 \mathrm{~g}$ for $10 \mathrm{~min}$ at $4^{\circ} \mathrm{C}$. Next, $80 \mu \mathrm{l}$ of the water phase is carefully transferred to another Eppendorf, 2.7 volumes of ethanol is added, and the RNA is immediately precipitated by centrifuging at $12,000 \mathrm{~g}$ for $20 \mathrm{~min}$ at $4^{\circ} \mathrm{C}$. The pellet is washed in cold $70 \%$ ethanol, vacuum-dried, and dissolved in $3 \mu \mathrm{l}$ of $\mathrm{H}_{2} \mathrm{O}$. This RNA is directly reversed-transcribed in $5 \mathrm{~mm} \mathrm{MgCl}_{2}$,
$50 \mathrm{~mm} \mathrm{KCl}, 10 \mathrm{~mm}$ Tris- $\mathrm{HCl}(\mathrm{pH} 8.3)$, $2.5 \mu \mathrm{M}$ random hexamers (Pharmacia), $1 \mathrm{~mm}$ each dNTP (Promega), $1 \mathrm{U} / \mu \mathrm{l}$ RNase inhibitor, and $2.5 \mathrm{U} / \mu \mathrm{l}$ Moloney murine leukemia virus (Mo-MLV) reverse transcriptase (GIBCO, BRL). A master mix of all reagents including the enzyme is prepared on ice and 17 $\mu l$ is added to each RNA sample. The samples are then incubated $10 \mathrm{~min}$ at room temperature followed by $45 \mathrm{~min}$ at $42^{\circ} \mathrm{C}$ and $5 \mathrm{~min}$ at $95^{\circ} \mathrm{C}$. The samples can then be frozen or directly amplified.

PCR is performed in $2 \mathrm{mM} \mathrm{MgCl}_{2}$, $50 \mathrm{mM} \mathrm{KCl}, 10 \mathrm{~mm}$ Tris- $\mathrm{HCl}(\mathrm{pH} \mathrm{8.3)}$, $0.2 \mathrm{~mm}$ each dNTP, and $2.5 \mathrm{U} / 100 \mu \mathrm{l}$ Taq DNA polymerase (Perkin-Elmer Cetus) and with $5 \mathrm{ng} / \mu \mathrm{l}$ of each specific primer. As for the reverse transcriptase reaction, a master mix of all PCR reagents including the enzyme is prepared and equally distributed in the different reaction tubes. An aliquot of the products of the reverse transcriptase reaction (1-5 $\mu \mathrm{l})$ is then added to each tube. Comparison of the levels of gene expression between different samples requires that the PCR reaction be stopped during the exponential phase of amplification. This can easily be determined by removing an aliquot at regular intervals during the PCR. With further experience of the behavior of the particular gene under study, an aliquot can be taken out at only two different times (e.g., after 22 and 25 cycles) to ensure that all samples are still within the exponential phase of amplification. In addition, to measure the efficiency of RNA extraction and of the reverse transcriptase reaction for each sample, the $\beta$-actin gene is amplified from a 1 - to $2-\mu \mathrm{l}$ aliquot of the same reverse transcription reaction and used as an internal standard.

All PCR products are run in an agarose gel and blotted onto nitrocellulose filters, which are then hybridized with the appropriate ${ }^{32}$ P-labeled plasmid probes. The signals obtained are quantified by densitometric analysis on an image analyzer (Research Analysis System R-1000, Amersham).

\section{EXAMPLE}

As a test gene, we chose the B-myb gene, which is expressed to an average level by the HL-60 cell line under normal conditions but becomes vir- 


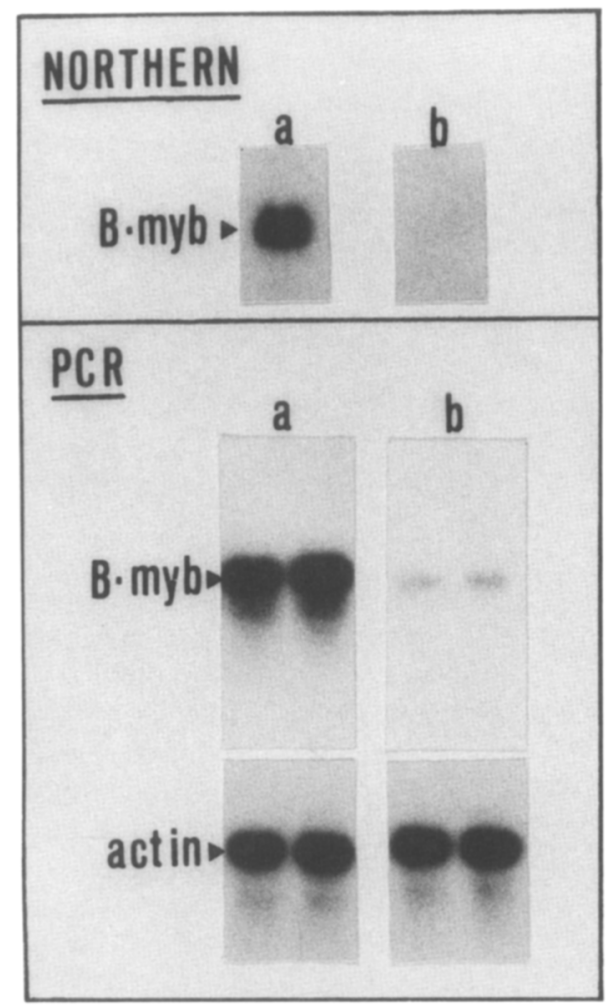

FIGURE 1 Comparison of B-myb gene levels measured in Northern blots or by PCR. HL60 cells were stimulated for $48 \mathrm{hr}$ with 10 $\mathrm{ng} / \mathrm{ml}$ of PMA. Total RNA was extracted in guanidium thiocyanate solution and purified on cesium chloride gradients. ${ }^{(3)}$ Levels of B-myb mRNA before (lane $a$ ) and after (lane $b$ ) PMA treatment were determined by standard Northern analysis (upper panel). Alternatively, the micromethod of RNA extraction was performed as described in duplicate on $2 \times 10^{3}$ HL-60 cells, before and after treatment with PMA for $48 \mathrm{hr}$ (lower panel, lanes $a$ and $b$, respectively). Each sample was then reversetranscribed in a total volume of $20 \mu \mathrm{l}$. For B$m y b$ amplification, a 5- $\mu$ l aliquot from each reverse-transcription reaction was then amplified in a $25-\mu 1$ volume for 24 cycles as follows: $1 \mathrm{~min}$ at $95^{\circ} \mathrm{C}, 2 \mathrm{~min}$ at $64^{\circ} \mathrm{C}$, and $2 \mathrm{~min} 30 \mathrm{sec}$ at $72^{\circ} \mathrm{C}$. The primers dATGTCTCGGCGGACGCGCTGCGAG and dGCCGTCCTTGTCCTCGAGCTCCAGC amplify a fragment of 633 bases. For $\beta$-actin amplification, $2-\mu \mathrm{l}$ aliquots were amplified by PCR for 22 cycles of 1 min each at $95^{\circ} \mathrm{C}$, $55^{\circ} \mathrm{C}$, and $72^{\circ} \mathrm{C}$. The primers dCCTTCCTGGGCATGGAGTCCTG and dGGAGCAATGATCTTGATCTTC amplify a fragment of 202 bases. A $10-\mu$ l aliquot of each reaction product was run in a $1.5 \%$ agarose gel, transferred to nitrocellulose, and hybridized with the appropriate ${ }^{32} \mathrm{p}$ labeled plasmid probes as described elsewhere. ${ }^{(3)}$ tually undetectable after stimulation of these cells for $48 \mathrm{hr}$ by phorbol esters (PMA), as determined by Northern blot analysis (Fig. 1, upper panel). RNA from $2 \times 10^{3}$ HL-60 cells before and after treatment with PMA for $48 \mathrm{hr}$ was extracted in duplicate, reverse-transcribed, and amplified with the appropriate primers under the conditions indicated in Figure 1. The results (Fig. 1, lower panel) demonstrate that the strong reduction in B-myb gene expression after PMA treatment is also detectable by PCR analysis, and to a level equivalent to that obtained by Northern analysis. The levels of $\beta$-actin measured by PCR are, on the other hand, unchanged after PMA treatment. The results also show that the method of RNA extraction, reverse transcription, and PCR gives good reproducibility because the intensity of the bands from duplicate samples differs by no more than $15 \%$ as determined by densitometric analysis.

It is important to note that this method also permits quantification of relative levels of specific mRNAs by constructing a standard curve using serial dilutions of RNA containing the gene of interest amplified in parallel to the unknown samples, as described in more detail in previous publications. ${ }^{(2)}$ The intensity of each band is measured by densitometric analysis and plotted. An example of such a standard curve for the B-myb gene is shown in Figure
2. Extrapolation of the values obtained for the HL-60 samples before and after treatment with PMA show that PMA reduces B-myb mRNA levels by $90-95 \%$ (Fig. 2), which is in reasonable agreement with the Northern data (Fig. 1).

\section{ACKNOWLEDGMENTS}

This work was supported by the Italian Association for Cancer Research, the Foundation Tettamanti, and a Fellowship from the Commission of the European Community to J.G. We thank Dr. S. Haskil and S. Becker for useful suggestions.

\section{REFERENCES}

1. Belyavsky, A., T. Vinogradova, and K. Rajevsky. 1989. PCR-based CDNA library construction: General cDNA libraries at the level of a few cells. Nucleic Acids Res. 17: 2919-2932.

2. Chelly, J., J.C. Kaplan, P. Maire, S. Gautran, and A. Kahn. 1988. Transcription of the dystrophin gene in human muscle and non-muscle tissues. Nature 333: 858-860.

3. Golay, J., A. Capucci, M. Arsura, M. Castellano, V. Rizzo, and M. Introna. 1991. Expression of $c-m y b$, but not A$m y b$, correlates with proliferation in human hematopoietic cells. Blood 7: 149-158.

Received July 8, 1991; accepted in revised form September 12, 1991.

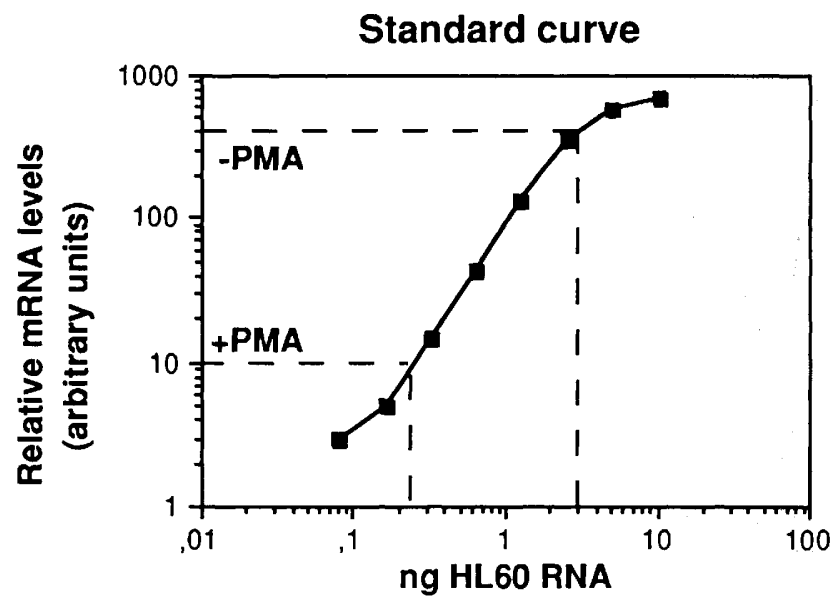

FIGURE 2 Standard curve for B-myb amplification. A total of 100 ng HL-60 RNA was reversetranscribed in $20 \mu \mathrm{l}$, and a $2-\mu \mathrm{l}$ aliquot and twofold dilution of it were amplified using the B$m y b$ primers as described in Fig. 1. The specific hybridization signals obtained were quantified by densitometric analysis and plotted. The average values for the signals obtained with HL-60 cells before and after treatment with PMA (396 and 10, respectively) are also indicated with dashed lines, showing that PMA reduces the levels of B-myb mRNA by $90-95 \%$ (from 3 to $0.23 \mathrm{ng}$ equivalent of HL-60 RNA). 


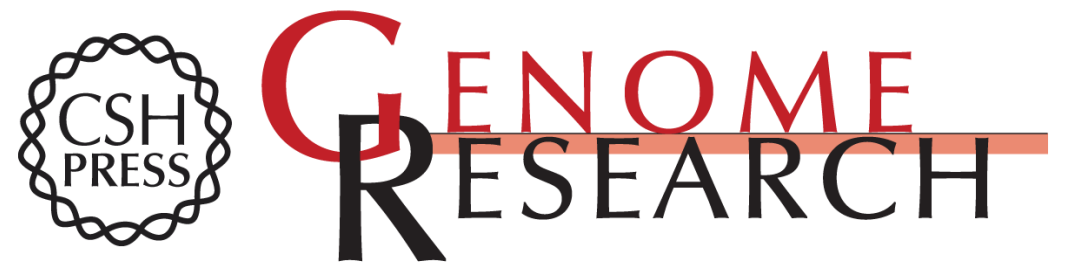

\section{A simple and rapid method to analyze specific mRNAs from few cells in a semi-quantitative way using the polymerase chain reaction.}

J Golay, F Passerini and M Introna

Genome Res. 1991 1: 144-145

Access the most recent version at doi:10.1101/gr.1.2.144

\section{License}

Email Alerting

Receive free email alerts when new articles cite this article - sign up in the box at the Service top right corner of the article or click here.

\section{Affordable, Accurate Sequencing.}

